\title{
IMPLEMENTASI PEMBELAJARAN DARING BERBASIS EDMODO PADA MATA KULIAH EVALUASI PROGRAM KEPELATIHAN DI MASA PANDEMI COVID-19
}

\author{
Sulia Ningsih \\ Program Studi Teknologi Pendidikan Universitas Baturaja \\ sulia_ningsih@fkip.unbara.ac.id
}

\begin{abstract}
Abstrak: Sistem pendidikan di Indonesia sejak awal tahun 2020 telah mengalami perubahan yang cukup signifikan akibat pandemi Covid-19. Pembelajaran daring menjadi solusi untuk mengurangi kemungkinan menyebarnya virus ini dengan menggunakan media online. Edmodo adalah salah satu media online yang dapat digunakan pada pembelajaran, termasuk pada mata kuliah Evaluasi Program Kepelatihan. Penelitian ini bertujuan untuk menganalisis implementasi pembelajaran daring berbasis edmodo yang digunakan untuk pembelajaran daring pada mata kuliah Evaluasi Program Kepelatihan. Metode penelitian yang digunakan adalah kualitatif deskriptif. Hasil penelitian menunjukkan bahwa (1) Pemilihan edmodo sebagai media pembelajaran daring pada mata kuliah Evaluasi Program Kepelatihan didasarkan pada analisis kebutuhan mahasiswa dengan alasan kemudahan dan penguasaan aplikasi. (2) Perencanaan pembelajaran daring berbasis edmodo tergambar di rencana pembelajaran semester (RPS); (3) Implementasi pembelajaran daring berbasis edmodo dilaksanakan berdasarkan RPS dengan baik dan lancar; (4) Edmodo membantu pelaksanaan evaluasi pembelajaran untuk mengukur hasil belajar mahasiswa.
\end{abstract}

Kata Kunci: implementasi, pembelajaran daring, edmodo, covid-19

\begin{abstract}
The education system in Indonesia since the beginning of 2020 has undergone significant changes due to the Covid-19 pandemic. Online learning is a solution to reduce the possibility of spreading this virus by using online media. Edmodo is an online media that can be used in learning, including in the Coaching Program Evaluation course. This study aims to analyze the implementation of edmodo-based online learning which is used for online learning in the Coaching Program Evaluation course. The research method used is descriptive qualitative. The results showed that (1) The selection of Edmodo as an online learning medium in the Coaching Program Evaluation course was based on an analysis of student needs on the grounds of ease and mastery of applications. (2) Edmodo-based online learning planning is reflected in the semester learning plan (RPS); (3) The implementation of edmodo-based online learning is carried out well and smoothly based on RPS; (4) Edmodo helps implement learning evaluations to measure student learning outcomes.
\end{abstract}

Keywords: implementation, online learning, edmodo, covid-19

\section{PENDAHULUAN}

Covid-19 merupakan virus yang merupakan virus RNA strain tunggal positif ini menginfeksi saluran pernafasan. Penegakan diagnosis dimulai dari gejala umum berupa demam, batuk, dan sulit bernafas hingga adanya kontak erat dengan Negara-negara yang sudah terinfeksi. Pengambilan swab tenggorokan dan saluran napas menjadidasar penegakan Diagnosis Coronavirus Disease (Yuliana, 2020: 192). Covid-19 bermula muncul dari Wuhan Cina sejak Akhir Januari 2020. Organisasai kesehatan dunia (WHO) telah menetapkan penomena kejadian itu sebagai pandemic (Mahase, 2020).

Pada saat ini Indonesia dihadapkan pada tantangan besar untuk menangani dan mencegah penyebaran virus Covid-19 yang semakin menyebar, yang berdampak pada semua aspek kehidupan, tidak tercuali bidang pendidikan. Salah satu upaya pencegahan sebaran Covid-19 yang dilakukan Kementerian pendidikan dan Kebudayaan terhadap lembaga pendidikan, yaitu dengan kebijakan belajar dari rumah, melalui pembelajaran daring dan disusul dengan kebijakan peniadaan Ujian Nasional untuk tahun ini (Rusdiana, Sulhan, Arifin, \& Kamludin, 2020).

Lembaga pendidikan sekolah/ perguruan tinggi sebagai ujung tombak pelayanan pendidikan pada level paling bawah. Para pimpinan Perguruan tingi/kepala sekolah dipaksa oleh keadaan untuk sesegera membuat suatu keputusan atau kebijakan teknis untuk merespon kebijakan surat edaran perintah dari mendikbud yang mengharuskan layanan pendidikakan atau "pembelajaran dari rumah" mulai dari Taman kanak-kanak sampai 
Perguruan tinggi (Kemendikbud, 2020).

Sistem pendidikan di perguruan tinggi berubah secara signifikan pada awal tahun 2020, khususnya pada bulan Maret 2020. Pada masa pandemi Covid-19 kegiatan pembelajaran tidak bisa dilaksanakan secara tatap muka di kelas. Pembatasan interaksi sosial di berbagai tempat mengharuskan pembelajaran dilakukan dengan sistem jarak jauh melalui jaringan. Pembelajaran dalam jaringan (daring) menjadi solusi agar pembelajaran tetap dapat dilakukan dimana saja dan kapan saja.

Pembelajaran daring merupakan pembelajaran yang dilakukan menggunakan internet sebagai tempat menyampaikan informasi dengan bentuk pembelajaran seperti yang dapat dilakukan kapanpun dan dimanapun tanpa terikat waktu dan tanpa harus bertatap muka dengan berbagai aplikasi dan fitur yang semakin memudahkan pengguna (Syarifudin, 2020).

Pembelajaran daring di Universitas Baturaja sebenarnya telah diterapkan oleh beberapa dosen sebelum pemberlakuan social distancing oleh pemerintah. Sebelumnya pembelajaran daring yang dilakukan berfungsi sebagai pelengkap pembelajaran sebagai variasi pembelajaran dan memberikan kemudahan belajar pada peserta didik. Namun implementasi pembelajaran daring pada masa pandemi Covid-19 dijadikan sebagai cara utama untuk tetap melaksanakan pembelajaran.

Penggunaan dan pemanfaatan berbagai platform online menjadi kemampuan yang harus dikuasai oleh dosen untuk implementasi pembelajaran daring. Salah satu platform online yang ditawarkan berdasarkan perkembangan ICT saat ini adalah media edmodo.

Edmodo dikembangkan berdasarkan prinsip-prinsip pengelolaan kelas berbasis kelompok dan juga sosial media. Edmodo sangat komprehensif sebagai sebuah course management system seperti Moodle, bedanya adalah aksesnya lebih cepat dan lebih mudah menggunakannya dengan menggunakan beberapa fitur yang fungsinya sama seperti course management system (Dharmawati, 2017). Dalam penggunaan edmodo bukan hanya dosen dan mahasiswa saja yang dapat berinteraksi, tetapi para orang tua mahasiswa juga dapat memiliki akun untuk ikut berkomunikasi dengan guru, agar dapat melihat perkembangan anaknya selama menjalani proses pembelajaran (Istiqomah \& Azizah, 2013). Edmodo menyediakan cara yang aman dan mudah bagi kelas untuk terhubung dan berkolaborasi antara siswa dan guru untuk berbagi konten pendidikan, mengelola proyek dan tugas dan menangani pemberitahuan setiap aktivitas. Edmodo dapat membantu pengajar membangun sebuah kelas virtual sesuai dengan kondisi pembelajaran di dalam kelas, berdasarkan pembagian kelas nyata di sekolah, dimana dalam kelas tersebut terdapat penugasan, quiz dan pemberian nilai pada setiap akhir pembelajaran (Putranti, 2013).

Implementasi pembelajaran daring berbasis edmodo pada mata kuliah Evaluasi Program Kepelatihan di masa pandemi Covid19 ditinjau dari beberapa aspek yaitu (1) Perencanaan pembelajaran Daring berbasis edmodo (2) Pelaksanaan pembelajaran daring berbasis edmodo (3) evaluasi pembelajaran daring berbasis edmodo pada mata kuliah Evaluasi Program Kepelatihan

\section{METODE PENELITIAN}

Pendekatan yang digunakan dalam penelitian ini adalah pendekatan deskriptif kualitatif. Penelitian kualitatif adalah jenis penelitian yang temuan-temuannya tidak diperoleh melalui prosedur statistik atau bentuk hitungan lainnya dan bertujuan mengungkapkan gejala secara holistik-kontekstual melalui pengumpulan data dari latar alami dengan menanfaatkan diri peneliti sebagai instrumen kunci (Sugiarto, 2015).

Objek dari penelitian ini yaitu media edmodo dalam mata kuliah Evaluasi Program Kepelatihan Program Studi Teknologi Pendidikan Universitas Baturaja. Subjek dari penelitian ini adalah dosen mata kuliah evaluasi program kepelatihan dan mahasiswa semester 6 Program Studi Teknologi Pendidikan Semester Genap Tahun Akademik 2019/2020. Data dalam penelitian ini didapatkan peneliti dari proses observasi yang dilakukan pada mahasiswa semester 6 dan dosen mata kuliah evaluasi program kepelatihan.

Peneliti melakukan observasi langsung terhadap proses pembelajaran tersebut. Teknik analisis data yang digunakan adalah reduksi data, pengumpulan data, penyajian data, serta verifikasi dan penarikan kesimpulan. Validasi data menggunakan triangulasi (gabungan). Penyajian data dilakukan dalam bentuk uraian singkat. 


\section{HASIL DAN PEMBAHASAN}

Penelitian ini menggambarkan tentang implementasi pembelajaran daring berbasis edmodo yang digunakan oleh mahasiwa semester 6 program studi teknologi pendidikan pada mata kuliah Evaluasi Program Kepelatihan.

Berdasarkan observasi langsung tentang pembelajaran daring berbasis edmodo pada mata kuliah Evaluasi Program Kepelatihan. dapat disimpulkan bahwa implementasi media pembelajaran daring berbasis edmodo memberikan kemudahan kepada dosen dan mahasiswa pada pembelajaran mata kuliah Evaluasi Program Kepelatihan.

Pembelajaran daring berbasis edmodo membuat kegiatan berlangsung secara interaktif antara dosen dan mahasiswa. Penggunaan edmodo tidak perlu melakukan proses instalasi yang rumit dan menu-menu yang mudah digunakan.

\section{Proses Pelaksanaan Pembelajaran Daring Berbasis Edmodo}

Proses pelaksanaan pembelajaran daring pada mata kuliah Evaluasi Program Kepelatihan di Semester Genap Tahun Akademik 2019/2020 dimulai pada tanggal 9 Maret 2020. Sesuai dengan dokumentasi yang didapatkan, pada pertemuan pertama dilakukan secara tatap muka. Kemudian masuk pada pertemuan kedua pada tanggal 16 Agustus 2020 dilakukan secara daring.

Berdasarkan hasil angket yang disebar melalui google form dengan responden 17 mahasiswa berkenaan dengan media online yang akan digunakan, 82,35\% mahasiswa memilih edmodo untuk digunakan karena alasan yang paling dikuasai pengoperasiannya dan $17,65 \%$ sisanya beralasan karena mudah pengoperasiannya.

Dosen yang telah memiliki akun edmodo sebagai pengajar kemudian membuat grup dengan nama "A61 Evaluasi Program Kepelatihan - 2020". Kemudian dosen meminta mahasiswa untuk bergabung di grup tersebut dengan menggunakan kode grup "kd67zp" sampai seluruh mahasiswa bergabung di dalam grup kelas virtual edmodo.

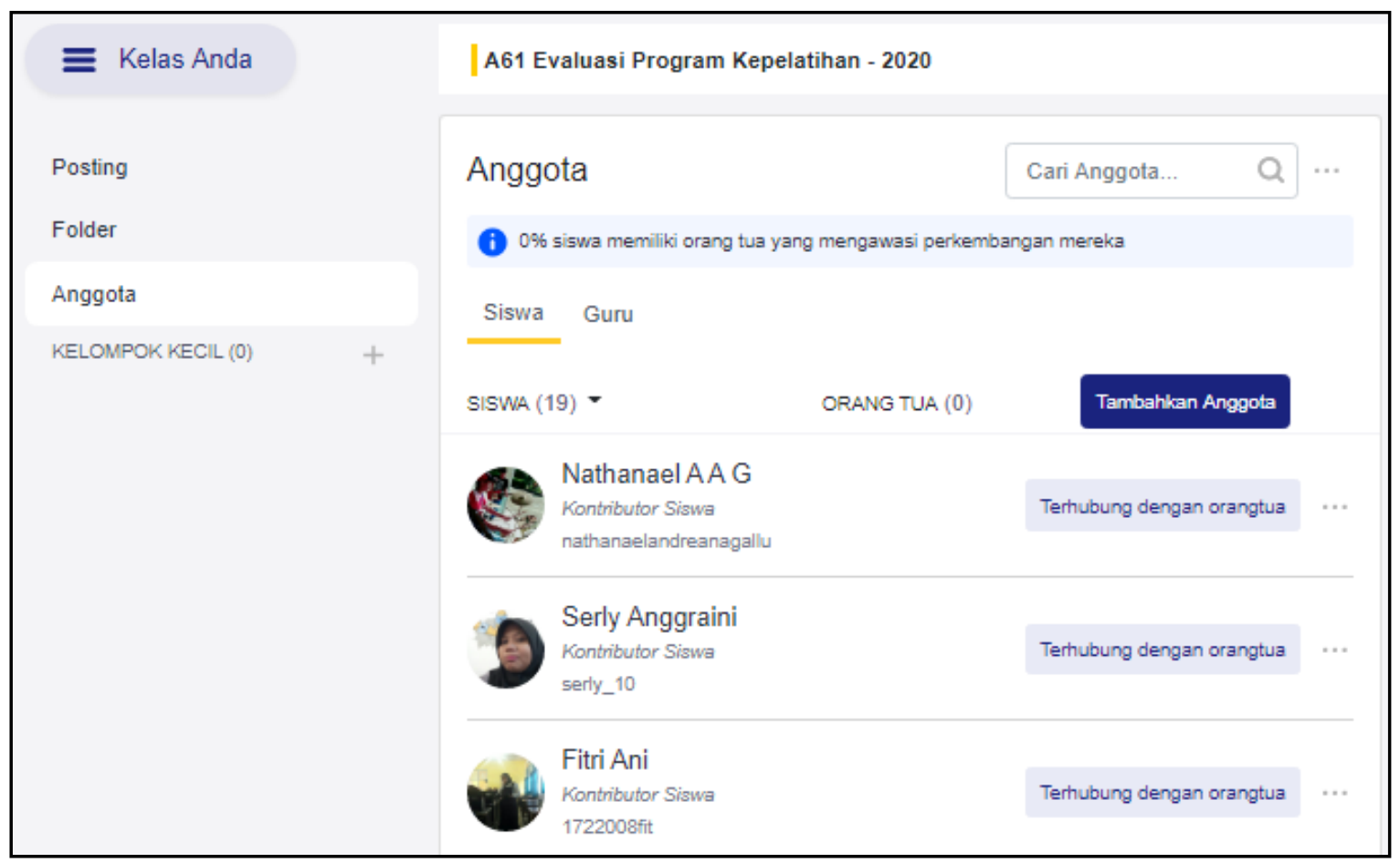

Gambar 1. Anggota Mahasiswa Mata Kuliah Evaluasi Program Kepelatihan

Selain mahasiswa, grup dikontrol oleh dosen pengajar pada mata kuliah Evaluasi Program Kepelatihan. 


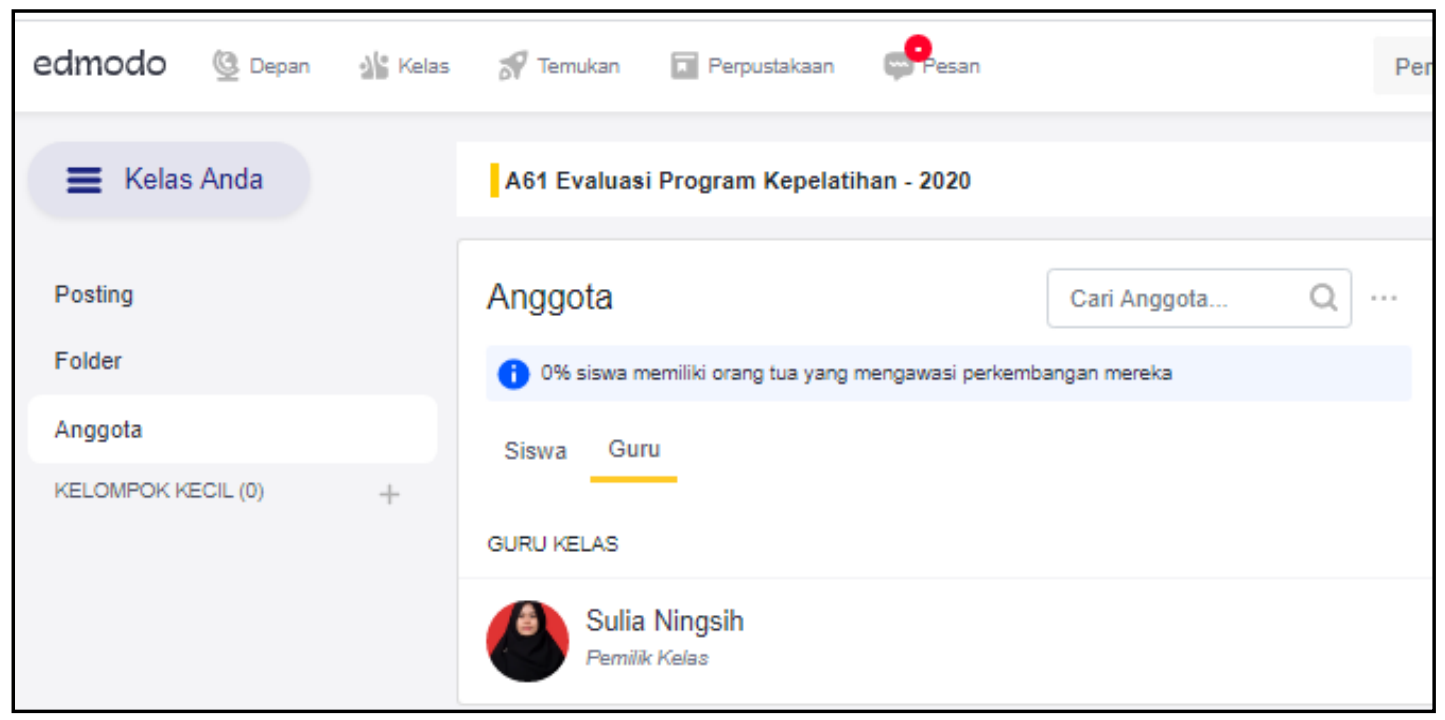

Gambar 2. Dosen Grup Mata Kuliah Evaluasi Program Kepelatihan

Pada perencanaan pembelajaran mata kuliah Evaluasi Progam Kepelatihan, dosen telah merencanakan menggunakan media/platform online edmodo sebagai variasi pembelajaran. Kemudian pada saat kebijakan belajar di rumah selama masa pandemi dengan menggunakan sistem daring, dosen mengkonfirmasi ulang kepada mahasiswa mengenai media/platform online yang akan digunakan.

Pada tahap perencanaan sebelum kegiatan perkuliahan berlangsung, dosen seperti biasa menyusun Rencana Pembelajaran Semester (RPS). Rencana Pembelajaran Semester (RPS) adalah dokumen perencanaan pembelajaran yang disusun sebagai panduan bagi mahasiswa dalam melaksanakan kegiatan perkuliahan selama satu semester untuk mencapai capaian pembelajaran yang telah ditetapkan (Syafarina \& Setiawan, 2019).

Berdasarkan dokumentasi yang dilakukan, RPS mata kuliah Evaluasi Program Kepelatihan disusun dengan menyesuaikan pembelajaran daring yang dilakukan dan di upload di akun edmodo kelas A61 Mata Kuliah Evaluasi Program Kepelatihan. RPS yang telah disusun kemudian di upload di grup "A61 Evaluasi Program Kepelatihan - 2020". Berdasarkan angket diperoleh informasi bahwa RPS yang telah disusun $88,23 \%$ membantu mahasiswa melaksanakan pembelajaran.

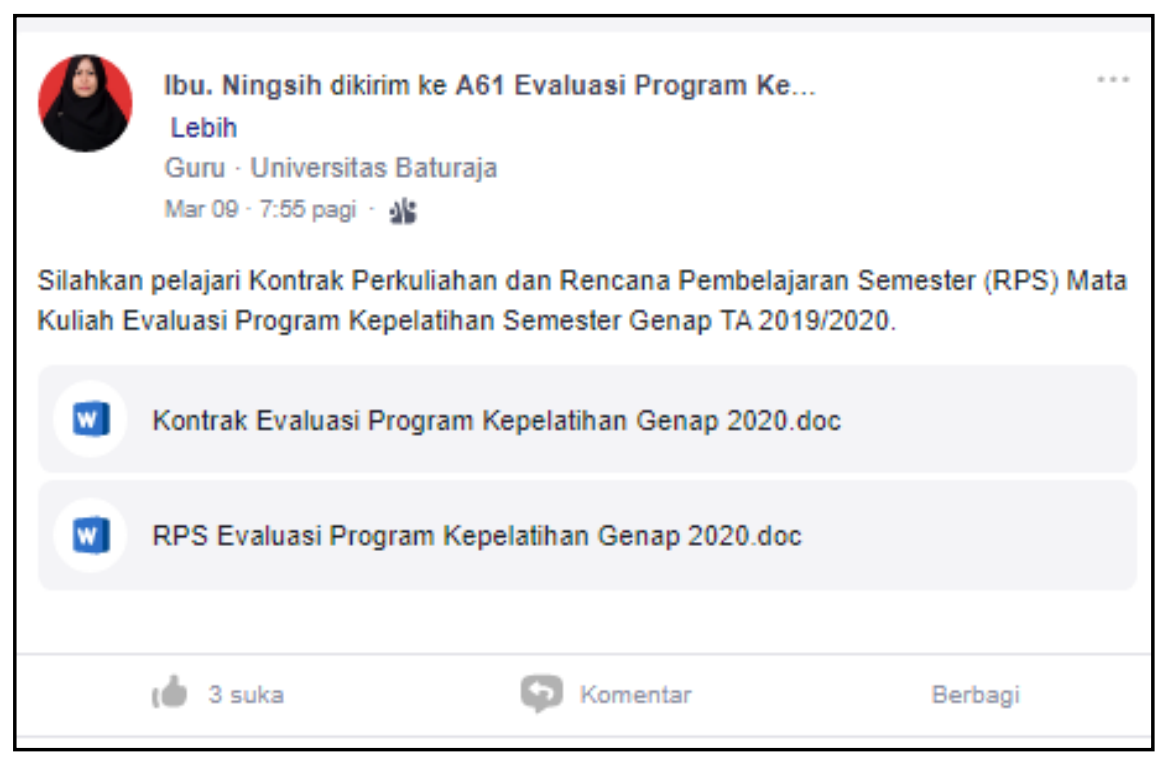

Gambar 3. Penyampaian RPS 
Berdasarkan hasil dokumentasi, pada tahap pelaksanaan pembelajaran daring dilakukan dengan beberapa metode yaitu diskusi online, tanya jawab, dan resitasi/penugasan. Metode yang digunakan diimplementasikan dengan memanfaatkan beberapa menu di aplikasi edmodo. Implementasi pembelajaran mata kuliah Evaluasi Program Kepelatihan yang dilaksanakan secara daring dengan memulainya menggunakan metode resitasi dan diskusi yaitu menugaskan mahasiswa untuk berdiskusi sesuai dengan pembagian kelompok.

Metode resitasi adalah pemberian tugas kepada siswa atau di luar jadwal pelajaran yang pada akhirnya dipertanggungjawabkan kepada guru yang bersangkutan. Metode resitasi merupakan salah satu pilihan metode mengajar seorang guru, dimana guru memberikan sejumlah item tes kepada siswanya untuk dikerjakan di luar jam pelajaran. Pemberian item tes ini biasanya dilakukan pada setiap kegiatan belajar mengajar di kelas, pada akhir setiap pertemuan atau akhir pertemuan di kelas (Aditya, 2016).

Edmodo akan menyediakan forum diskusi online antar mahasiswa dan dosen. Forum diskusi online merupakan media penyalur aspirasi masyarakat berupa ide, gagasan, maupun pertanyaan. Ide, gagasan maupun pertanyaan tersebut lebih dikenal dengan istilah informasi. Dalam informasi tersebut berisi text, gambar, atau video. Forum komunikasi ini dapat kita gunakan sebagai sarana media komunikasi antar pengguna internet (Kurniawan, Suprianto, \& Sumardiyono, 2016).

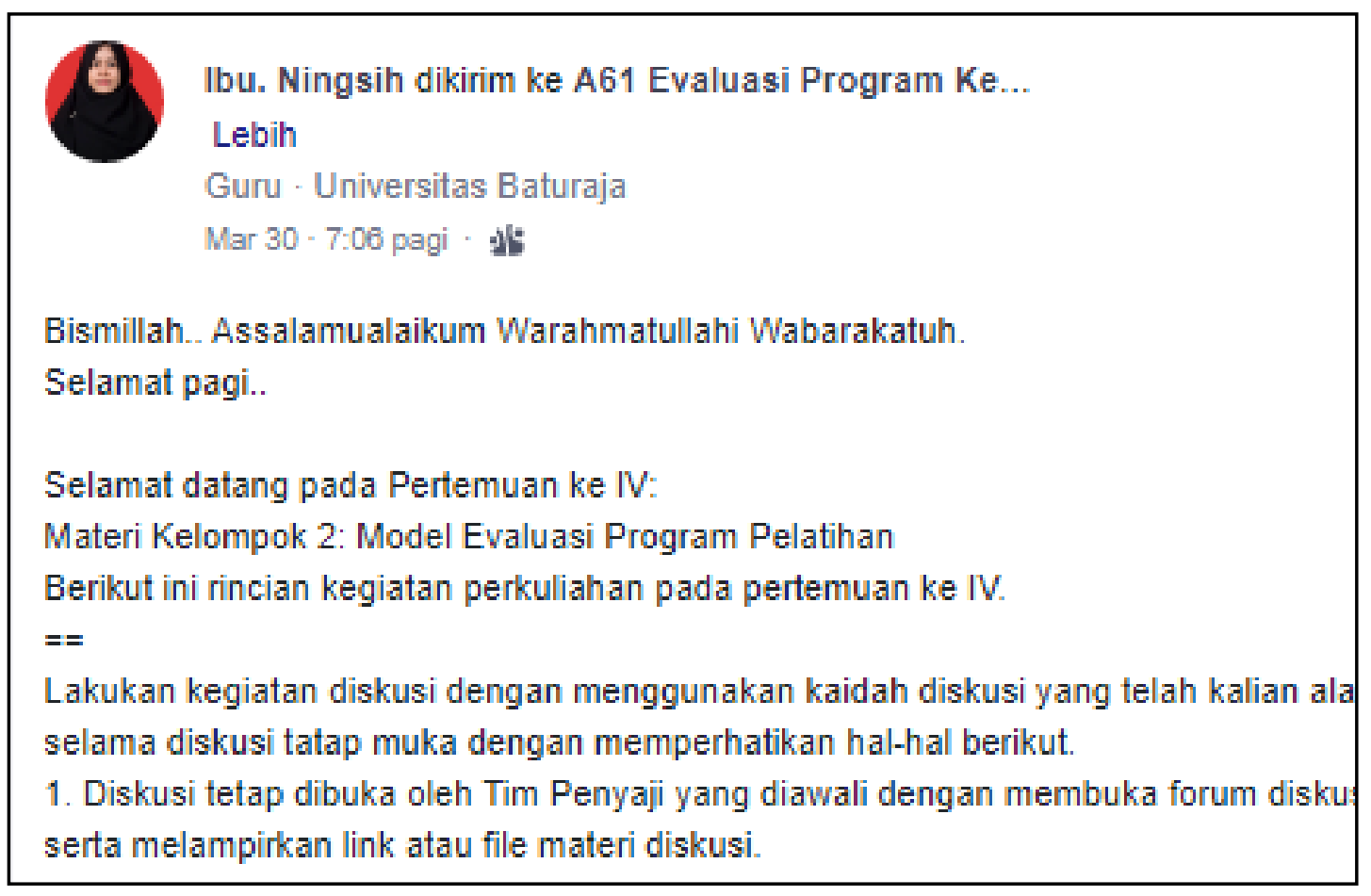

Gambar 4. Intruksi kegiatan diskusi online

Pada kegiatan dikusi online tersebut, dosen membuka sesi tanya jawab untuk membantu mahasiswa memahami materi.

Metode tanya jawab adalah metode pembelajaran di mana materi ajar disampaikan dalam bentuk tanya jawab antara guru dengan siswa dan sesama siswa. Keberhasilan penggunakan metode tanya jawab dalam kegiatan pembelajaran sangat ditentukan oleh penguasaan teknik atau keterampilan guru dalam menyampaikan dan menjawab pertanyaan (Merona, 2017).

Setiap pertemuan dimulai dengan absensi virtual dengan memanfaatkan menu tugas/assigmen di edmodo. Tiap mahasiswa diminta untuk turn ini untuk mengisi teks hadir dengan batas waktu yang ditentukan. Hal ini dilakukan untuk mengontrol kedisiplinan mahasiswa dalam pembelajaran daring.

Kedisiplinan merupakan kontribusi 
mengikuti dan menaati peraturan sekolah yang meliputi dapat mengatur waktu belajar di rumah, rajin dan teratur belajar, perhatian yang baik saat belajar di kelas dan keter tiban diri saat belajar di kelas (Tu'u, 2004).

Diplin belajar mahasiswa adalah satu kunci yang dapat mewujudkan suasana belajar menjadi kondusif dan optimal. Idealnya siswa yang mengikuti pembelajaran di kelas memiliki perhatian yang baik saat belajar (Tu'u, 2004), dapat mematuhi tata tertib, menepati jadwal/waktu (Arikunto, 1990:137), dapat berpartisipasi aktif, memiliki kesopanan, memiliki kehadiran yang baik di kelas (khuluse, 2009:9).

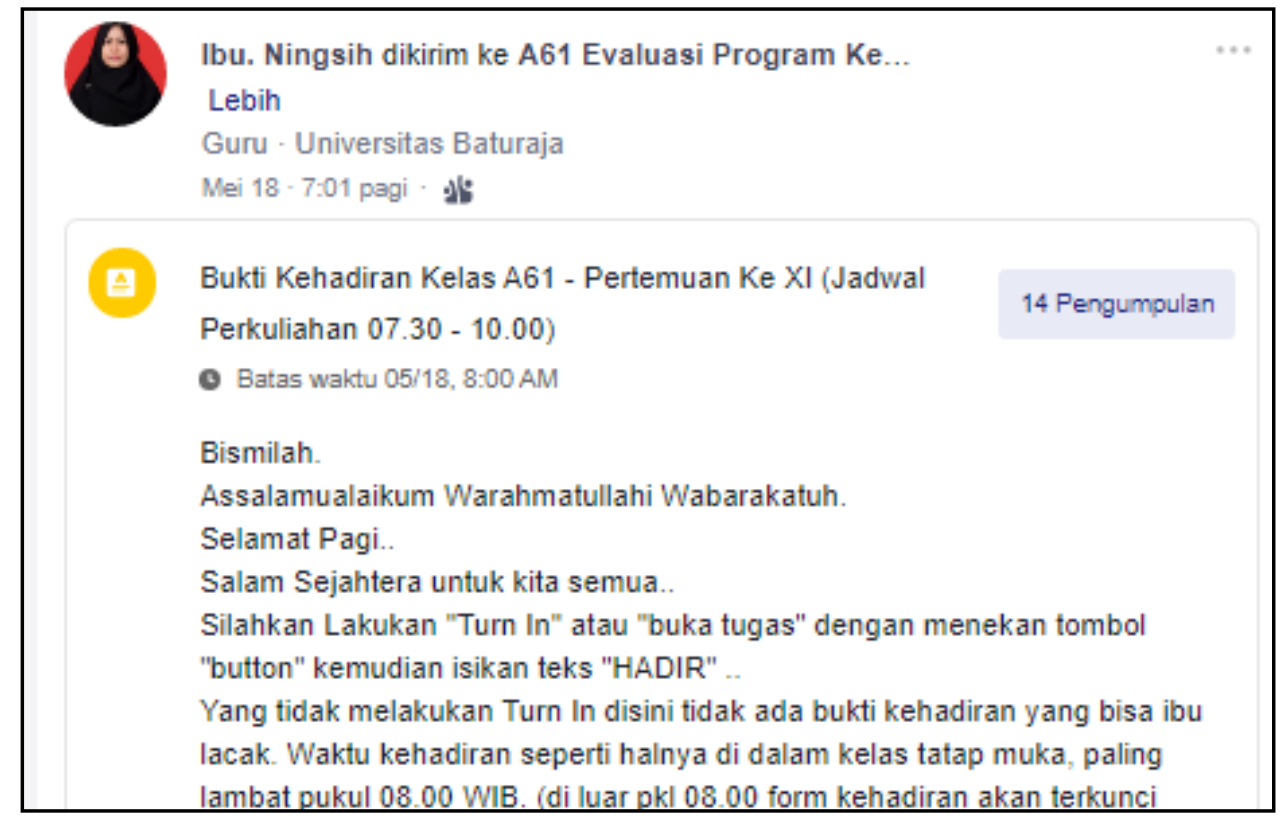

Gambar 5. Intruksi Bukti Kehadiran

Selain kegiatan diskusi dan tanya bimbingan tugas akhir melalui bimbingan jawab, dosen memberikan tugas berupa mandiri melalui menu "assigment".

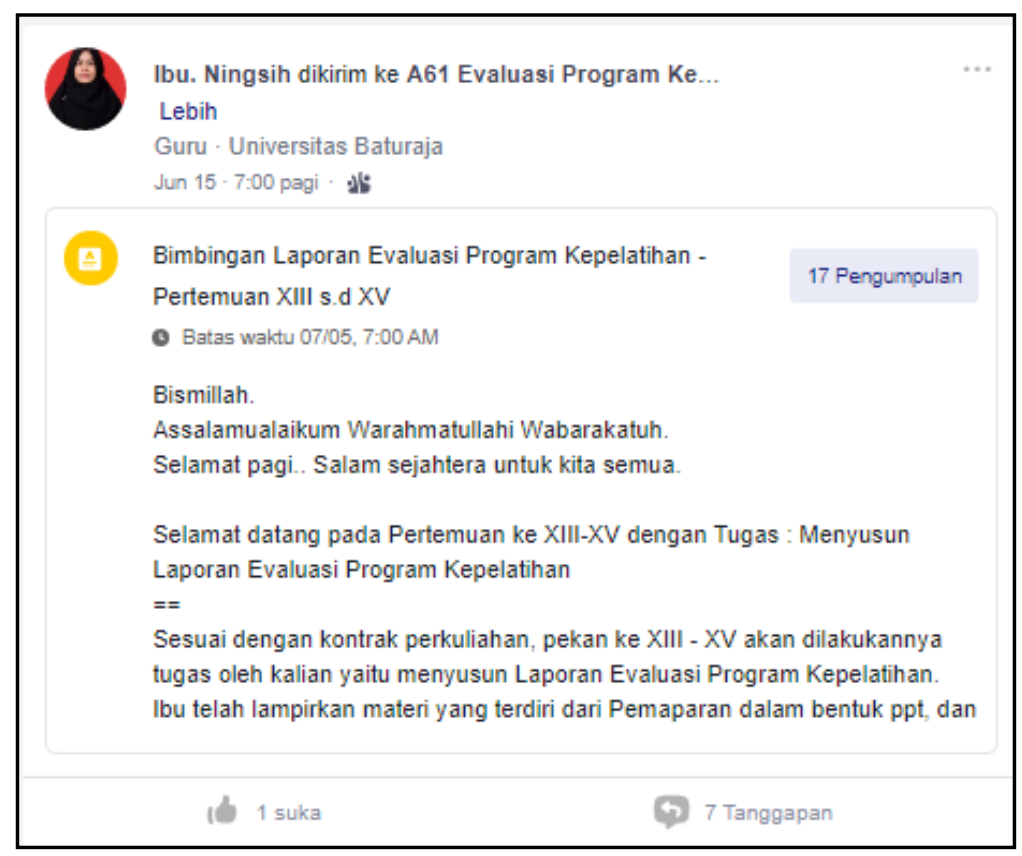

Gambar 6. Bimbingan Daring Berbasis Edmodo 
Selain sebagai upaya mengurangi kontak fisik dan penerapan social distancing pada masa pandemi Covid-19, bimbingan melalui edmodo secara online (internet) memberikan banyak manfaat. Dengan memanfaatkan internet, maka bimbingan dapat dilakukan secara online dan mahasiswa tidak membuang membuang biaya untuk mencetak proposal yang akan dikoreksi dan dicoret-coret oleh dosen pembimbing untuk perbaikan. Hal ini tentu akan menghemat biaya dari sisi kertas dan biaya cetak. Mahasiswa juga hanya perlu mengirimkan file laporan kepada dosen serta dosen akan mengoreksi draft laporan tersebut dan memberikan koreksi dalam bentuk file sehingga lebih efektif dan efisien (Putra \& Arkan, 2017).

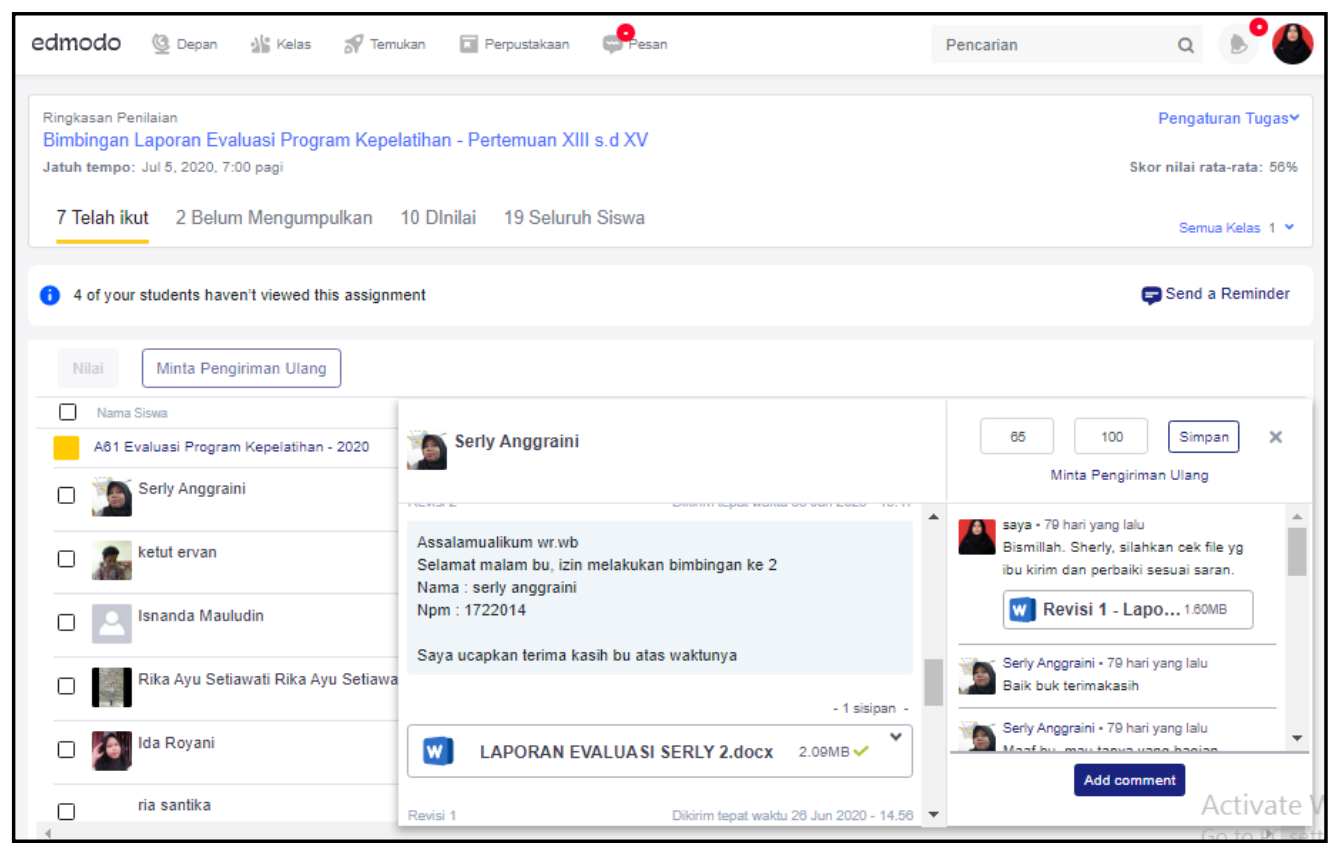

Gambar 7. Proses Bimbingan Laporan secara Daring Berbasis Edmodo

Pada tahap evaluasi, dosen bertujuan untuk mengetahui hasil belajar mahasiswa pada mata kuliah Evaluasi Program Kepelatihan. Kegiatan belajar dan mengajar sasarannya adalah hasil belajar, jika cara dan motivasi belajar baik, maka diharapkan hasil belajarnya juga baik. Sudjana menyatakan bahwa hasil belajar adalah kemampuan yang dimiliki oleh siswa setelah ia menerima pengalaman belajar (Sudjana, 2011). Istilah hasil belajar tersusun atas dua kata, yakni: "hasil" dan "belajar". Menurut Alwi "hasil" berarti sesuatu yang diadakan (dibuat, dijadikan) oleh suatu usaha, sedangkan "belajar" mempunyai banyak pengertian diantaranya adalah belajar merupakan perubahan yang terjadi dalam diri seseorang setelah melalui proses (Alwi, 2003).

Pada tahap evaluasi mata kuliah Evaluasi Program Kepelatihan, dosen melakukan penilaian sebanyak dua kali, yaitu Ujian Tengah Semester (UTS) dan Ujian Akhir Semester (UAS). Ujian tengah semester (UTS) atau mid semester dilakukan sesuai dengan RPS yaitu pada pertemuan ke VIII dengan sistem online/daring. Dosen memberikan petunjuk pelaksanaan UTS dan dilengkapi dengan soal UTS yang telah divalidasi oleh program studi. Berdasarkan hasil dokumentasi diketahui bahwa $100 \%$ mahasiswa di kelas A61 hadir keseluruhan untuk mengikuti ujian tengah semester yaitu berjumlah 17 orang mahasiswa. 


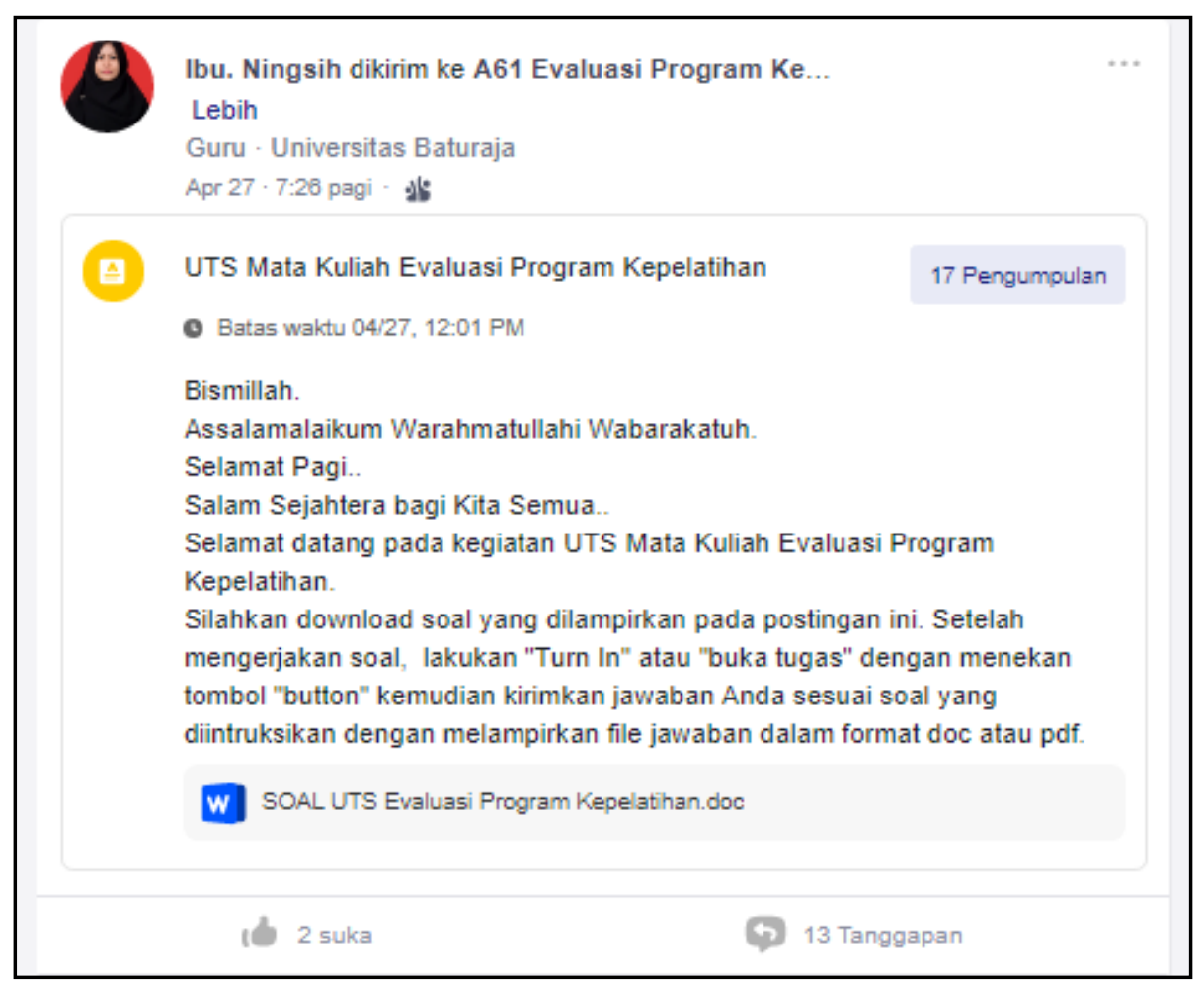

Gambar 8. UTS Daring Berbasis Edmodo

Kegiatan evaluasi kedua yaitu Ujian Akhir Semester (UAS) pada minggu ke XVI atau minggu terakhir dengan sistem daring berbasis edmodo. Seperti halnya pada UTS, dosen memberikan petunjuk pelaksanaan UAS dan soal yang telah divalidasi oleh program studi. Berdasarkan hasil dokumentasi diketahui bahwa 16 orang mahasiswa $(94,11 \%)$ di kelas
A61 mengikuti ujian akhir semester, 1 (5,88\%) mahasiswa lainnya mengerjakan secara menyusul dan tidak bisa masuk pada sistem dikarenakan sitem tugas terkunci otomatis jika mahasiswa terlambat mengerjakan. Pengaturan ini digunakan untuk mengontrol kedisiplinan mahasiswa.

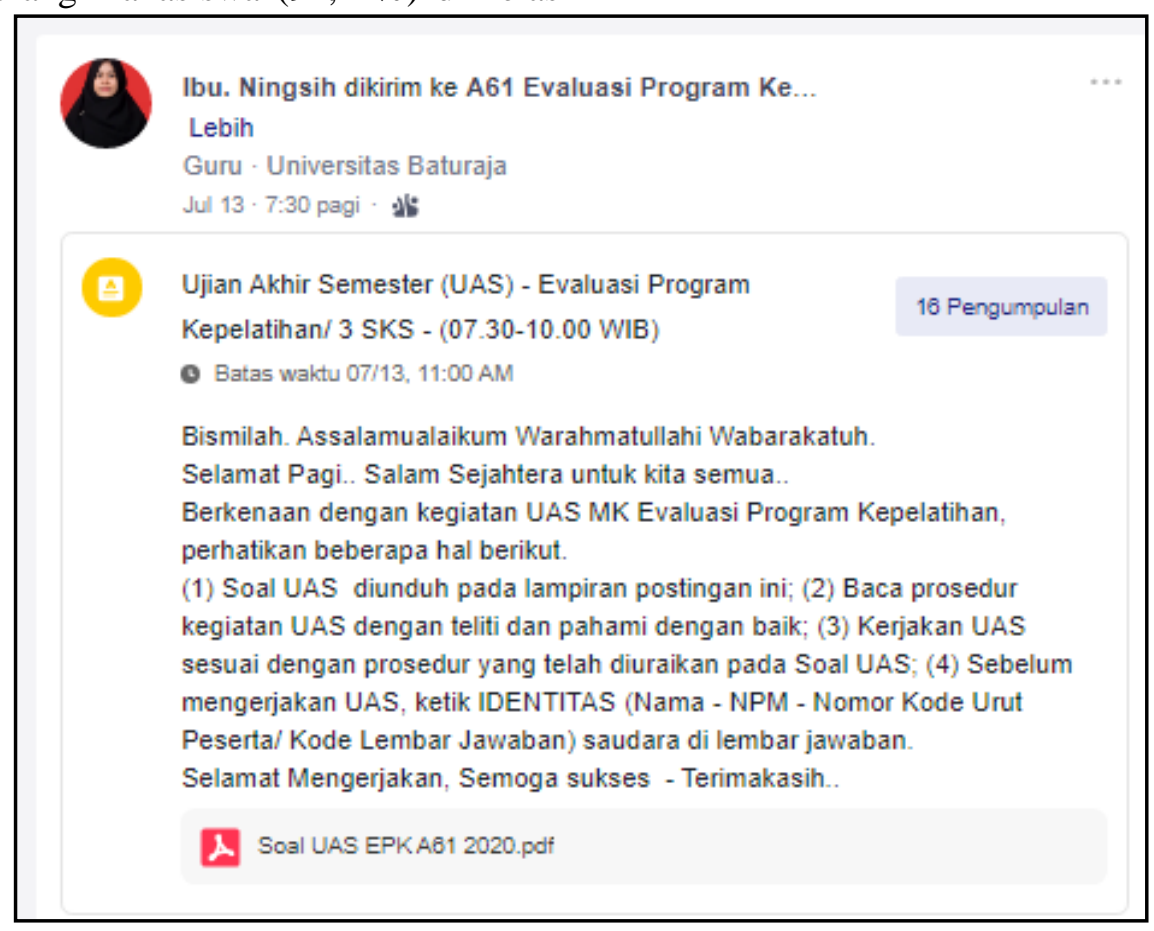

Gambar 9. UAS Daring Berbasis Edmodo 


\section{Keuntungan dan Kendala Pembelajaran Daring Berbasis Edmodo}

Penggunaan internet sudah menjadi hal yang vital dalam penyediaan sumber referensi untuk penelitian dan belajar bagi guru dan peserta didik untuk berbagi dan memperoleh informasi. Perkuliahan atau pembelajaran daring adalah merupakan pembelajaran berbasis teknologi yang mencakup penggunaan internet dan hal- hal penting lainnya seperti menghasilkan bahan untuk belajar, mengajar peserta didik, dan juga mengatur pembelajaran (Arkorful \& Abaidoo, 2015).

Di masa pandemi ini, perkuliahan dilakukan dengan jarak jauh dimana mahasiswa dan dosen tetap berada di rumah. Meski berada di rumah, namun perkuliahan tetap dilaksanakan yaitu dengan pelaksanaan perkuliahan daring secara fleksibel dan kemudahan untuk mengakses.

Hal ini sesuai dengan pendapat Lopes dimana keunggulan pembelajaran daring adalah fleksibilitas dan aksesibiltas (Lopes, 2012). Di samping itu, pembelajaran yang dikembangkan di website atau dalam bentuk Learning Management System (LMS) memiliki keuntungan menyediakan konten untuk peserta didik di mana saja. Hal ini memungkinkan akses yang lebih cepat daripada metode pembelajaran konvensional.

Hal ini juga sesuai pendapat Arkorful bahwa terdapat beberapa keuntungan ketika menerapkan perkuliahan daring diantaranya adalah: (1) fleksibiltas, peserta didik memiliki kesempatan untuk memilih waktu dan tempat yang cocok untuknya; (2) dapat meningkatkan pengetahuan karena kemudahan mengakses sejumlah besar informasi; (3) memberikan peluang lebih besar bagi peserta didik dalam forum diskusi online karena dapat menghilangkan hambatan seperti ketakutan untuk berbicara; (4) Daring dinilai hemat biaya karena tidak perlu mengeluarkan uang untuk melakukan perjalanan; (5) dapat membantu mengkompensasi kurangnya staf akademik, termasuk instruktur atau guru serta fasilitator teknisi lab, dan lain-lain; (6) penggunaan daring memungkinkan peserta didik belajar sesuai dengan kecepatannya sendiri, misalnya pada cara asinkron (Arkorful \& Abaidoo, 2015).

Implementasi pembelajaran daring berbasis edmodo pada mata kuliah Evaluasi Program Kepelatihan dapat dikatakan lancar. Hal ini ditinjau dari pelaksanaan pembelajaran yang tetap berjalan sesuai waktu yang telah ditetapkan. Kehadiran mahasiswa di setiap pertemuan rata-rata $80 \%$ mahasiswa. Pengumpulan tugas dan keaktifan diskusi mahasiswa juga menjadi acuan mengukur kelancaran pelaksanaan pembelajaran.

Namun pada beberapa pertemuan jumlah kehadiran mahasiswa menurun dengan beberapa alasan. Berdasarkan angket yang disebar ke mahasiswa diperoleh informasi bahwa kendala mahasiswa di beberapa pertemuan pada pembelajaran daring berbasis edmodo yaitu jaringan internet. Mahasiswa yang sebagian besar telah pulang kampung di daerah pedesaan kesulitan untuk memperoleh jaringan internet yang baik. Kesulitan lainnya adalah mahasiswa sulit memahami beberapa materi yang sifatnya keterampilan misalnya penyusunan laporan.

Hal ini sesuai dengan pendapat Arkorful \& Abaidoo yang menyatakan beberapa kekurangan perkuliahan daring diantaranya adalah: (1) menyebabkan peserta didik kurang berinteraksi satu sama lain; (2) klarifikasi, penjelasan, dan interpretasi dalam metode daring mungkin kurang efektif dibandingkan pembelajaran tradisional karena pembelajaran tradisional lebih banyak dan lebih mudah bertatap mula langsung dengan instruktur atau guru; (3) kurang mendukung dalam hal peningkatan keterampilan, daring mungkin dapat meningkatkan pengetahuan dengan sangat baik tetapi efeknya dalam meningkatkan keterampilan sangat kecil; (4) tidak semua disiplin ilmu dapat menggunakan daring secara efektif dalam pendidikan. Misalnya bidang ilmiah yang membutuhkan pengalaman praktis mungkin lebih sulit untuk dipelajari dalam daring; (5) dapat menyebabkan kemacetan akses atau penggunaan berat (overload) beberapa situs web. Ini dapat menyebabkan hal yang tak terduga baik dalam hal biaya maupun waktu (Arkorful \& Abaidoo, 2015).

\section{PENUTUP}

Berdasarkan hasil penelitian dan pembahasan yang dikemukakan sebelumnya, maka dapat simpulkan bahwa implementasi 
pembelajaran daring berbasis edmodo pada mata kuliah Evaluasi Program Kepelatihan berjalan lancar mulai dari perencanaan dengan RPS yang berorientasi daring, proses pembelajaran menggunakan edmodo melalui diskusi online, tanya jawab dan resitasi, serta

\section{DAFTAR PUSTAKA}

Aditya, D. Y. (2016). Pengaruh Penerapan Metode Pembelajaran Resitasi terhadap Hasil Belajar Matematika Siswa. SAP (Susunan Artikel Pendidikan), 1(2), 165174. https://doi.org/10.30998/sap.v1i2.10

Alwi, Hasan. 2003. Kamus Besar Bahasa Indonesia. Jakarta: Balai Pustaka

Arikunto, Suharsimi. (1990). Manejemen Pengajaran Secara Manusiawi. Jakarta: PT Penelitian. Bandung: Pustaka Setia

Arkorful, V., \& Abaidoo, N. (2015). The Role of E-learning, Advantages and Disadvantages of Its Adoption in Higher Education. International Journal of Instructional Technology and Distance Learning, 12(1), 29-42.

Dharmawati. (2017). Penggunaan Media ELearning Berbasis Edmodo dalam Pembelajaran English for Business QUERY: Jurnal Sistem Informasi. Jurnal Sistem Informasi, 1(1), 43-49

Istiqomah, S., \& Azizah, N. (2013). Penerapan Metode Blended Learning Berbasis Ict Untuk Meningkatkan Minat Dan Prestasi Belajar Pada Mata Kuliah Ilmu Sosial Budaya Dasar (Isbd) Di Prodi D-Iii Kebidanan Fik Unipdu Jombang. Jurnal EduHealth, 3(2), 245718.

Kemendikbud (2020). Cegah Sebaran Covid-19 di Satuan Pendidikan, Kemendikbud Gandeng Swasta Siapkan Solusi Belajar Daring (Siaran Pers BKH Kemendikbud Nomor: 054/SIPRES/A6/ III/2020. 15 Maret 2020).

Khuluse, N. L. (2009). The effect of discipline on academic achievement in secondary school. Dissertation master of education. Department of Educational Psychology and Special Needs Education. Faculty of Educationat. University of Zululand.

Kurniawan, W., Suprianto, A., \& Sumardiyono, B. (2016). Rancangan Sistem Forum Diskusi Online Untuk Program Studi Sistem Informasi Antara Dosen Dan Mahasiswa. Jurnal Rekayasa Informasi, 5(2), 43-51. kegiatan evaluasi (UAS dan UTS) yang dijalankan secara online. Disamping itu, pembelajaran daring berbasis edmodo ini juga mengalami kendala seperti jaringan internet yang terbatas dan kesulitan memahami materi yang bersifat keterampilan.

Lopes, A. P. (2012). Learning Management Systems in Higher Education. In Virtual Learning Environments (pp. 1249-1264). https://doi.org/10.4018/978-1-46660011-9.ch608

Mahase, E. (2020). Coronavirus Covid-19 has Killed more People than SARS and MERS combined, Despite Lower Case Fatality Rate. BMJ (Clinical Research Ed.), 368(February), m641. https://doi.org/10.1136/bmj.m641

Merona, S. P. (2017). Kombinasi Tutorial dengan Metode Tanya Jawab untuk Meningkatkan Pemahaman Matematika Di Perguruan Tinggi, 6(2), 153-162.

Putra, G. B., \& Arkan, F. (2017). Implementasi Sistem Bimbingan Tugas Akhir Mahasiswa Berbasis Web Server dan Android. E-Issn:2541-2361, Issn 25412361, 02(01), 137-145. Retrieved from http://eproceeding.undiksha.ac.id/index.p $\mathrm{hp} / \mathrm{semnasvoktek/article/view/707}$

Putranti, N. (2013). Cara Membuat Media Pembelajaran Online Menggunakan Edmodo. Jurnal Pendidikan Informatika Dan Sains, 2(2), 139-147.

Rusdiana, A., Sulhan, M., Arifin, I. Z., \& Kamludin, U. A. (2020). Penerapan Model POE2WE Berbasis Blended Learning Google Classroom Pada Pembelajaran Masa WFH Pandemic Covid-19. Karya Tulis Ilmiah UIN Bandung 2020, 1-10.

Sudjana, Nana. (2011). Penilaian Hasil Proses Belajar Mengajar. Bandung: Remaja Rosdakarya.

Sugiarto, E. (2015). Menyusun Proposal Penelitian Kualitatif Skripsi dan Tesis. Penelitian. https://doi.org/10.1021/ol7029646

Syafarina, G. A., \& Setiawan, A. (2019). Perancangan Aplikasi Rencana Pembelajaran Semester (RPS) untuk Meningkatkan Pencapaian Pembelajaran Bagi Dosen, 10(4), 186-195.

Syarifudin, A. S. (2020). Impelementasi Pembelajaran Daring Untuk Meningkatkan Mutu Pendidikan Sebagai 
Jurnal Teknologi Pendidikan, Vol. 13, No. 2, Oktober 2020, e-ISSN: 2407-7437

Dampak Diterapkannya Social Distancing. Jurnal Pendidikan Bahasa Dan Sastra Indonesia Metalingua, 5(1), 31-34. https://doi.org/10.21107/metalingua.v5i1. 7072

Tu'u, T. (2004). Peran Disiplin Pada Perilaku dan Prestasi Siswa, Jakarta: PT. Gramedia Widia Sarana Indonesia. 